\title{
Analisis Efisiensi Distribusi Labu Siam di Kabupaten Semarang
}

\section{Analysis Distribution Efficiency of Chayote in Semarang Regency}

\author{
Syam Lingga Wijaya ${ }^{1^{*}}$, Siswanto Imam Santoso ${ }^{2}$, Wiludjeng Roessali ${ }^{3}$ \\ ${ }^{1 *}$ Jurusan Pertanian, Fakultas Peternakan dan Pertanian, Universitas Diponegoro \\ Jalan Prof. H. Soedarto S. H., Tembalang, Kec. Tembalang, Kota Semarang, Jawa Tengah \\ ${ }^{2,3}$ Program Studi Agribisnis, Fakultas Peternakan dan Pertanian, Universitas Diponegoro \\ Jalan Prof. H. Soedarto S. H., Tembalang, Kec. Tembalang, Kota Semarang, Jawa Tengah
}

Diterima: 17 Juli 2019; Direvisi: 26 Agustus 2019; Disetujui: 25 November 2019

\begin{abstract}
ABSTRAK
Tujuan penelitian ini adalah menganalisis saluran distribusi labu siam (Sechium edule (Jacq.) Sw), menganalisis marjin dan efisiensi distribusi pada setiap pola distribusi, dan menganalisis perbedaan marjin distribusi antar pola distribusi labu siam. Penelitian dilaksanakan pada bulan Februari sampai Maret 2019. Metode analisis data dalam penelitian menggunakan analisis deskriptif kuantitatif. Jumlah responden dalam penelitian ini sebanyak 54 orang dengan rincian 16 orang petani, 8 orang tengkulak, 8 orang pedagang pengumpul pasar, 9 orang pedagang besar, dan 13 orang pedagang pengecer. Jumlah responden petani ditentukan dengan quota sampling dan responden lembaga distribusi ditentukan dengan snowball. Hasil penelitian menunjukkan bahwa terdapat lima pola distribusi labu siam di Kabupaten Semarang. Efisiensi distribusi labu siam pada pola I dan pola II berdasarkan nilai marjin distribusi dan farmer's share diketahui telah efisien, sedangkan pola III, pola IV, dan pola V tidak efisien. Pola saluran I adalah pola saluran yang paling efisien berdasarkan nilai farmer's share, nilai efisiensi, dan nilai MME.
\end{abstract}

Kata kunci : efisiensi distribusi; farmer's share; labu siam; saluran distribusi

\section{ABSTRACT}

The purpose of the study were to analyze the distribution channel of chayote (Sechium edule (Jacq.) Sw., the distribution margins and distribution efficiency in each distribution pattern, and the differece in each distribution pattern. The research was conducted on Ferbruary to March 2019. The method used for data analysis are quantitative descriptive analysis. The number of respondents in this study are 54 people with a total of 16 farmers, 8 middlemen, 8 market traders, 9 wholesalers, and 13 retailers. The number of farmers respondents determined with quota sampling and the distribution institution respondents determined by snowball sampling based on farmers information. The result showed that there are five patterns of distribution of chayote in Semarang Regency. Chayote distribution efficiency in pattern I and II based on margin of distribution value and farmer's share are efficient while pattern III, IV, and V are inefficient. The most efficient distribution pattern is pattern I based on farmer's share value, efficiency value, and MME value.

Key word : chayote; distribution efficiency; distribution channel; farmer's share

\section{How to Cite:}

Wijaya, S. L., Santoso, S. I., Roessali, W., H, J. P. H. S. S., Tembalang, K., Semarang, K., \& Tengah, J. (2019). Analisis Efisiensi Distribusi Labu Siam di Kabupaten Semarang. HABITAT, 30(3), 96-104. https://doi.org/10.21776/ub.habitat.2019.030.3.12

\section{Pendahuluan}

Labu siam (Sechium edule (Jacq.) Sw.) adalah komoditas hortikultura yang sering dikonsumsi oleh masyarakat Indonesia sebagai pendamping makanan pokok, komoditas ini sangat mudah dijumpai dalam bentuk mentah maupun olahan. Data di Badan Pusat Statistik
Jawa Tengah (2017) menunjukkan bahwa komoditas labu siam merupakan salah satu tanaman yang mendominasi jumlah produksi sayuran semusim pada tahun 2015 yaitu sebesar 161.755 ton.

Kabupaten Semarang adalah produsen tertinggi ke dua di Jawa Tengah untuk komoditas 
labu siam setelah Kabupaten Wonosobo. Volume produksi tahun 2017 di Kabupaten Semarang adalah 2.378 ton dengan area panen seluas 80 hektar (BPS Kabupaten Semarang, 2018). Kecamatan Sumowono, Kecamatan Bandungan, dan Kecamatan Getasan adalah 3 daerah produsen labu siam tertinggi di Kabupaten Semarang.

Labu siam pada dasarnya termasuk komoditas hortikultura, dimana komoditas ini membutuhkan banyak tempat dalam penyimpanan maupun penyaluran produknya ke konsumen akhir. Dastagiri (2013) berpendapat bahwa perkembangan komoditas hortikultura cenderung terhambat karena susunan sistem distribusi yang kurang baik dimana timbul kesenjangan atau selisih harga yang cukup tinggi antara harga jual di tingkat produsen dan harga beli di tingkat konsumen. Hasil penelitian ini menunjukkan bahwa distribusi produk dari petani akan selalu bermuara pada tengkulak sebelum sampai ke mata rantai selanjutnya. Penyaluran produk kepada tengkulak didasarkan pada ketiadaan fasilitas transportasi yang dimiliki petani dan menyebabkan petani sebagai pihak price taker dimana petani akan mengetahui harga jual produk mereka setelah produk laku terjual di pasar. Perilaku produsen tersebut dijelaskan oleh pendapat Kheirandish dan Gowda (2012) bahwa sebagian besar petani tidak memiliki fasilitas distribusi serta jumlah produksinya relatif sedikit, sehingga mereka memilih untuk menjual produk mereka ke tengkulak atau pedagang lokal di daerah mereka karena ketidak-mungkinan petani kecil untuk masuk ke pasar secara individu.

Lembaga distribusi akan melakukan fungsi pemasaran yang berbeda-beda dimana fungsi pemasaran tersebut membutuhkan biaya distribusi yang akan menyebabkan perbedaan harga di tingkat produsen dan konsumen, namun petani sebagai produsen labu siam dalam penelitian ini tidak mengeluarkan biaya distribusi karena hasil panen akan diambil oleh tengkulak di lahan para petani. Semakin banyak lembaga distribusi yang terlibat dalam pemasaran sebuah produk, biaya distribusi pun bertambah sehingga menyebabkan selisih harga produk di tingkat produsen dan konsumen semakin tinggi. Hal tersebut sesuai dengan pendapat Alamaini et al, (2016) bahwa nilai marjin distribusi produk dipengaruhi oleh besar kecilnya biaya distribusi dan keuntungan

\footnotetext{
*Penulis Korespondensi

E-mail: syamlingga89@yahoo.co.id

Telp: +62-85-878123096
}

yang diperoleh setiap lembaga perantara yang terlibat, dimana semakin besar biaya distribusi maka harga jual akan semakin tinggi. Ketergantungan petani terhadap lembaga distribusi mengakibatkan harga yang diterima petani memiliki porsi yang sedikit dalam sebuah rantai distribusi. Berdasarkan uraian di atas, perlu diketahui bagaimana kinerja distribusi labu siam di Kabupaten Semarang.

Penelitian ini bertujuan untuk (1) menganalisis pola saluran pemasaran labu siam (2) menganalisis marjin dan efisiensi distribusi labu siam pada tiap pola, dan (3) menganalisis perbedaan marjin distribusi antar pola distribusi labu siam di Kabupaten Semarang secara statistik.

\section{Metode Pelaksanaan}

\subsection{Pendekatan Penelitian}

Penelitian dilaksanakan pada bulan Februari - Maret 2019 di Kecamatan Sumowono, STA Jetis, dan Kabupaten Semarang. Penelitian dilakukan dengan menggunakan metode snowball yaitu mengambil sampel dari populasi dan melakukan wawancara terhadap sampel dengan didasarkan pada kuesioner sebagai panduan. Penelitian dilaksanakan di Kecamatan Sumowono kemudian dilanjutkan ke STA Jetis. Kecamatan Sumowono dipilih sebagai lokasi penelitian karena wilayah tersebut merupakan sentra produksi labu siam di Kabupaten Semarang. STA Jetis merupakan salah satu pusat transaksi produk pertanian berdasarkan informasi dari petani dan tengkulak di Kecamatan Sumowono, sehingga produk labu siam dari tengkulak akan dijual di lokasi tersebut.

Penelitian ini melibatkan 53 responden secara keseluruhan, dengan rincian responden petani sebanyak 16 orang, 8 orang responden tengkulak, 8 orang responden pedagang pengumpul, 8 orang responden pedagang besar, dan 13 orang responden pedagang pengecer. Responden petani ditentukan dengan quota sampling, dimana jumlah sampel ditentukan oleh peneliti dengan dasar bahwa seluruh petani sampel akan menyetorkan produknya kepada tengkulak di wilayah penelitian dan harga yang diperoleh dari tengkulak adalah sama, harga jual yang diterima oleh setiap petani akan sama pada hari produk tersebut disetorkan sehingga untuk mengetahui harga jual pada tingkat petani, jumlah responden petani dianggap dapat mewakili populasi petani secara keseluruhan. Responden lembaga distribusi seperti tengkulak, pedagang pengumpul, 
pedagang besar, dan pedagang pengecer diperoleh dengan menggunakan metode snowball.

\subsection{Metode Analisis Data}

Data yang dikumpulkan meliputi data primer dan sekunder. Saluran distribusi produk dianalisis secara deskriptif, yaitu menggambarkan hasil pengamatan dari keseluruhan lembaga distribusi yang terlibat serta pola-pola yang terbentuk dalam penyaluran produk labu siam di Kabupaten Semarang. Saluran distribusi produk adalah hal yang sangat penting dalam proses transaksi. Ruauw (2015) menyatakan bahwa saluran distribusi melibatkan rangkaian organisasi yang saling memiliki ketergantungan satu sama lain dalam mempersiapkan produk menjadi produk siap pakai. Jarang dijumpai dalam proses transaksi hanya terdapat petani dan konsumen tanpa adanya lembaga perantara. Pradika dkk (2013) berpendapat bahwa dalam perekonomian modern atau perekonomian yang telah mengalami kemajuan, sangat jarang dijumpai pola penyaluran produk secara langsung dari produsen ke konsumen akhir, akan tetapi sebagian besar saluran distribusi akan melibatkan peran lembaga perantara dalam menyalurkan produk.

a. Marjin distribusi

Menurut Adiansyah dkk (2013) marjin distribusi diperoleh dari persamaan berikut :

Keterangan :

$$
M i=H c i-H p i(1)
$$

$\mathrm{Mi}=$ Marjin distribusi

Hci = Harga jual di tingkat pedagang pengecer $(\mathrm{Rp} / \mathrm{Kg})$

Hpi = Harga jual di tingkat produsen $(\mathrm{Rp} / \mathrm{Kg})$

b. Farmer's share

Menurut Muslim dan Darwis (2012) nilai

farmer's share diperoleh dari persamaan berikut :

$$
\mathrm{FS}=\frac{H p}{H e} \times 100 \%
$$

Keterangan :

FS = farmer's share

$\mathrm{Hp} \quad=$ harga jual di tingkat petani $(\mathrm{Rp} / \mathrm{Kg})$

$\mathrm{He} \quad=$ harga beli di tingkat konsumen akhir $(\mathrm{Rp} / \mathrm{Kg})$

Pola distribusi dikatakan efisien apabila nilai famer's share atau bagian yang diperoleh produsen dalam pola tersebut $>50 \%$ (Sudiyono, 2002). Mempertimbangkan bahwa petani menanggung resiko paling besar dalam rantai distribusi, maka semakin besar porsi harga yang diterima petani akan semakin adil sistem distribusi. Azzaino (1991) menyatakan bahwa suatu proses distribusi dikatakan efisien jika persentase farmer's share lebih besar dari persentase marjin distribusi. Semakin besar nilai farmer's share maka efisiensi distribusi pada pola tersebut semakin baik.

c. Efisiensi distribusi

Menurut Soekartawi (2002) nilai efisiensi distribusi diperoleh dari persamaan sebagai berikut :

Keterangan :

$$
\mathrm{EP}=\frac{T B}{T N P} \times 100 \%(3)
$$

EP : efisiensi distribusi

TB : total biaya distribusi

TNP : total nilai produk

Apabila :

Efisiensi distribusi $=0-33 \%$ : maka saluran distribusi efisien,

efisiensi distribusi $=34-67 \%$ : maka saluran distribusi kurang efisien,

efisiensi distribusi $=68-100 \%$ : maka saluran distribusi tidak efisien.

Acharya dan Agrawal (2001) memformulasikan perhitungan efisiensi distribusi secara matematis yang disebut modified marketing efficiency (MME), persamaannya adalah sebagai berikut :

Keterangan :

$$
M M E=\frac{F P}{(M C+M M)}
$$

MME = Modified marketing efficiency

$\mathrm{FP} \quad=$ harga yang diterima oleh petani

$\mathrm{MC}=$ total biaya distribusi

$\mathrm{MM}=$ total marjin distribusi

\section{Hasil dan Pembahasan}

\subsection{Struktur Rantai Distribusi Labu Siam}

Labu siam yang telah dipanen akan melewati beberapa pihak sebelum akhirnya dapat dikonsumsi oleh konsumen. Pihak-pihak yang terlibat dalam rantai distribusi labu siam adalah petani, tengkulak, pedagang pengumpul, pedagang besar, pedagang pengecer, dan konsumen. Pola distribusi biasanya didasarkan pada harga beli yang ditawarkan oleh setiap lembaga. Struktur rantai distribusi yang terjadi di Kabupaten Semarang dapat dilihat pada Gambar 1. Berdasarkan Gambar 1. diketahui bahwa labu siam dapat disalurkan secara langsung dari petani ke konsumen dan dapat disalurkan secara tidak langsung melalui lembaga distribusi. Kotler dan Amstrong (2004) menyatakan bahwa saluran distribusi dibagi menjadi 2 yaitu saluran langsung dan saluran tidak langsung, dimana produk akan 
disalurkan dari produsen langsung ke konsumen pada saluran langsung, dan pada saluran tidak langsung akan melibatkan peran distributor dalam rantai distribusinya.

Penyaluran produk pertanian secara langsung atau tidak langsung tergantung pilihan petani, tetapi dalam penelitian ini tidak ditemukan petani yang menyalurkan produknya langsung ke konsumen melainkan melalui perantara lembaga distribusi. Pelaku atau lembaga distribusi labu siam secara keseluruhan di Kabupaten Semarang adalah petani, tengkulak, pedagang pengepul pasar, pedagang besar, pedagang pengecer, dan konsumen.

a. Petani
Petani adalah produsen labu siam dan pelaku rantai distribusi yang paling awal di Kabupaten Semarang. Petani adalah orang yang membudidayakan dan mengusahakan tanaman labu siam di Kabupaten Semarang. Keberadaan petani dalam rantai distribusi ini sangat penting, karena ketersediaan labu siam sangat bergantung pada mereka. Berdasarkan penelitian, petani dapat memperoleh hasil sebanyak 0,7 ton dalam sekali panen dengan harga jual $\mathrm{Rp} 1.512,5 / \mathrm{Kg}$. Seluruh petani responden yang membudidayakan labu siam akan menjual hasil panennya ke tengkulak di desa mereka masing-masing dan menerima pembayaran sesuai dengan harga pasar pada hari penjualan hasil panen.

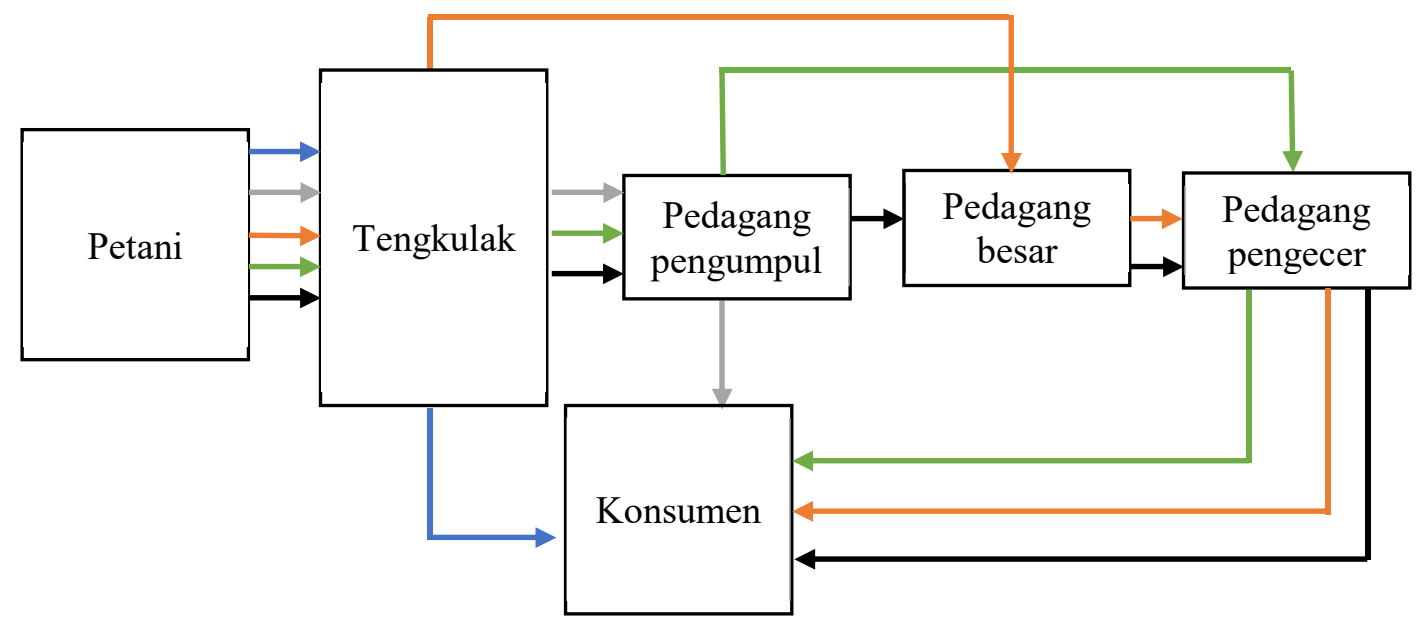

Gambar 1. Pola Distribusi Labu Siam

Keterangan :

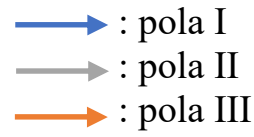

b. Tengkulak

Tengkulak adalah salah satu komponen atau mata rantai pada rantai distribusi labu siam. Peran tengkulak sangat penting bagi petani labu siam yang tidak memiliki akses maupun fasilitas untuk menjual langsung hasil panen ke lembaga distribusi di luar desa. Tengkulak dalam rantai distribusi labu siam berperan untuk menyalurkan hasil panen petani ke pedagang pengepul pasar, pedagang besar, atau langsung ke konsumen. Kapasitas transaksi harian tengkulak berdasarkan penelitian adalah 519,9 Kg. Harga jual grosir adalah Rp 1.962,5/Kg sedangkan harga jual eceran adalah $\mathrm{Rp} 2.375 / \mathrm{Kg}$.

\section{c. Pedagang pengumpul pasar}

Pedagang pengumpul pasar adalah salah satu mata rantai pada rantai distribusi labu siam.
Pedagang pengumpul pasar membeli labu siam dari tengkulak dan menjualnya langsung di lokasi (STA Jetis) baik kepada pedagang besar, pedagang pengecer, maupun langsung ke konsumen. Pedagang pengumpul pasar dapat menjual produknya secara borongan maupun eceran. Rata-rata transaksi harian oleh pedagang pengepul pasar adalah $272,5 \mathrm{Kg}$ dengan harga jual borongan $\mathrm{Rp} 2.362,5 / \mathrm{Kg}$ dan harga eceran $\mathrm{Rp} 2.875,0 / \mathrm{Kg}$.

\section{d. Pedagang besar}

Pedagang besar adalah pedagang yang membeli labu siam dalam jumlah yang cukup besar lalu disalurkan keluar dari lokasi pembelian (STA Jetis). Rata -rata transaksi labu siam di STA Jetis oleh pedagang besar adalah sebesar 398,44 $\mathrm{kg}$ yang kemudian dijual dengan harga $\mathrm{Rp}$ $3.583,3 / \mathrm{Kg}$. Pedagang besar akan membawa transportasi sendiri, membeli hasil panen kemudian disalurkan ke pedagang pengecer di pasar tradisional maupun pedagang keliling. 


\section{e. Pedagang pengecer}

Pedagang pengecer adalah pedagang yang membeli labu siam kemudian dijual kembali kepada konsumen. Jarang dijumpai pedagang pengecer yang membeli produk langsung ke petani, sebagian besar pedagang pengecer membeli produk melalui pedagang pengumpul pasar atau pedagang besar. Pedagang pengecer yang memiliki akses ke STA Jetis dapat membeli labu siam ke pedagang pengumpul, sedangkan bagi pedagang pengecer lainnya akan membeli labu siam di pedagang besar. Lokasi penjualan labu siam oleh pedagang besar relatif lebih terjangkau oleh pedagang pengecer yang membeli dalam jumlah sedikit daripada harus membeli langsung ke STA Jetis. Rata - rata transaksi harian oleh pedagang pengecer adalah sebesar $17 \mathrm{Kg}$ dengan harga jual Rp 4.880,77/Kg.

\subsection{Saluran Distribusi}

Distribusi adalah sebuah proses menyalurkan barang atau jasa yang terjadi di dalam pasar, sesuai dengan pendapat Sari (2014) yang menyatakan bahwa distribusi adalah proses menyalurkan produk yang diproduksi oleh produsen kepada konsumen melalui berbagai perantara guna memenuhi kebutuhan. Terdapat beberapa pola distribusi labu siam di Kabupaten Semarang, dari beberapa pola distribusi yang ditemukan produk tersebut selalu disalurkan melalui lembaga distribusi. Pola distribusi labu siam di Kabupaten Semarang dapat dilihat pada Gambar 1. Berdasarkan Gambar 1. dapat diketahui bahwa dalam penyaluran produk labu siam di Kabupaten Semarang selalu melibatkan lembaga distribusi dalam rantainya. Keberadaan lembaga dalam rantai distribusi labu siam dinilai sangat penting dalam proses menyalurkan produk ke konsumen, terlebih bagi petani yang tidak memiliki akses langsung ke pasar atau ke konsumen akhir. Hal ini sesuai dengan pendapat Said dan Intan (2004) bahwa sistem distribusi adalah kesatuan urutan lembaga distribusi yang melakukan fungsi - fungsinya demi kelancaran aliran produk dari produsen ke konsumen dan aliran uang dari konsumen ke produsen. Keterlibatan lembaga distribusi tentunya akan menimbulkan perbedaan harga. Hal tersebut sesuai dengan pernyataan Fuad, et al (2000) yang menyatakan bahwa apabila lembaga yang terlibat dalam rantai distribusi terlalu sedikit maka persebaran produk menjadi lebih sempit wilayahnya, sedangkan apabila terlalu banyak lembaga distribusi yang terlibat maka biaya distribusi semakin besar dan berkemungkinan menimbulkan pemborosan waktu.

\subsection{Marjin Distribusi}

Marjin distribusi merupakan selisih harga beli di tingkat konsumen dengan harga jual di tingkat produsen. Marjin distribusi dapat dijabarkan menjadi total biaya distribusi dan keuntungan yang diperoleh setiap lembaga distribusi yang terlibat dalam rantai distribusi produk. Irawan (2007) menyatakan bahwa komponen biaya distribusi sendiri dipengaruhi oleh sifat produk yang diperjual belikan serta risiko kerusakan produk saat distribusi berlangsung. Perlakuan seperti pengangkutan, sortasi, dan grading produk akan mempengaruhi marjin distribusi sebuah produk. Komponen biaya distribusi dalam penelitian ini terdiri dari biaya transportasi, biaya tiket atau karcis, biaya penimbangan, dan biaya tenaga kerja. Analisis marjin distribusi dan biaya distribusi pada pola I, II, III, IV, dan V ditunjukkan pada Tabel 1. Berdasarkan Tabel 1. diketahui bahwa pola distribusi I menimbulkan marjin distribusi sebesar $\mathrm{Rp} 862,5 / \mathrm{Kg}$ dan nilai farmer's share sebesar $63,7 \%$; pola distribusi II menimbulkan marjin distribusi sebesar $\mathrm{Rp} 1.362,5 / \mathrm{Kg}$ dan nilai farmer's share sebesar 52,6\%; pola distribusi III memiliki marjin distribusi total sebesar $\mathrm{Rp} 3.458,5 / \mathrm{Kg}$ dengan nilai farmer's share sebesar 30,4\%; pola distribusi IV memiliki marjin distribusi total sebesar $\mathrm{Rp} 3.262,5 / \mathrm{Kg}$ dan nilai farmer's share sebesar $31,8 \%$; pola distribusi $\mathrm{V}$ menimbulkan marjin distribusi sebesar Rp 3.458,5/Kg dan nilai farmer's share sebesar $30,4 \%$. Diketahui juga biaya distribusi pada pola I adalah sebesar Rp 74,00/kg, pola II memiliki total biaya distribusi sebesar $\mathrm{Rp} 148,33 / \mathrm{Kg}$, pola III memiliki total biaya distribusi sebesar Rp $290,31 / \mathrm{Kg}$, pola distribusi IV memiliki total biaya distribusi sebesar Rp 258,26 dan pola V memiliki total biaya distribusi sebesar Rp 219,69.

Perbedaan harga beli di tingkat konsumen menimbulkan perbedaan marjin distribusi, apabila dilihat dari lembaga distribusi yang terlibat dalam pola distribusi yang ditemukan, semakin banyak lembaga distribusi yang terlibat maka semakin tinggi marjin distribusi komoditas labu siam. Hal tersebut didukung oleh pendapat Fuad, et al (2000) bahwa semakin banyak lembaga distribusi yang terlibat maka biaya distribusi akan semakin besar. Lembaga distribusi yang terlibat akan memperhitungkan biaya yang mereka keluarkan dalam proses distribusi produk labu siam. 
Tabel 1. Analisis Marjin Distribusi Labu Siam Per Kilogram di Kabupaten Semarang

\begin{tabular}{|c|c|c|c|c|c|}
\hline \multirow{2}{*}{ Lembaga } & \multirow{2}{*}{ Uraian } & \multicolumn{2}{|c|}{ Pola I } & \multicolumn{2}{|c|}{ Pola II } \\
\hline & & $\begin{array}{c}\text { biaya } \\
--(\mathrm{Rp})--\end{array}$ & $\begin{array}{l}\text { Share } \\
--(\%)--\end{array}$ & $\begin{array}{l}\text { Biaya } \\
\text {-(Rp)- }\end{array}$ & $\begin{array}{l}\text { Share } \\
--(\%)--\end{array}$ \\
\hline Petani & a. Harga Jual & $1.512,5$ & 63,7 & $1.512,5$ & 52,6 \\
\hline \multirow{5}{*}{ Tengkulak } & a. Harga Beli & $1.512,5$ & 63,7 & $1.512,5$ & 52,6 \\
\hline & b. Biaya Distribusi & 74,05 & 3,1 & 74,05 & 2,6 \\
\hline & c. Marjin Distribusi & 862,5 & 36,3 & 450,0 & 15,7 \\
\hline & d. Profit & 788,5 & 33,2 & 376,0 & 13,1 \\
\hline & e. Harga Jual & $2.375,0$ & 100,00 & $1.962,5$ & 68,3 \\
\hline \multirow{5}{*}{ Pengepul Pasar } & a. Harga Beli & - & - & $1.962,5$ & 68,3 \\
\hline & b. Biaya Distribusi & - & - & 74,28 & 2,6 \\
\hline & c. Marjin Distribusi & - & - & 912,5 & 31,7 \\
\hline & d. Profit & - & - & 838,5 & 29,2 \\
\hline & e. Harga Jual & - & - & $2.875,0$ & 100,00 \\
\hline \multicolumn{2}{|c|}{ Total Biaya $(\mathrm{Rp} / \mathrm{Kg})$} & 74,05 & & 148,33 & \\
\hline
\end{tabular}

Tabel 1. (Lanjutan)

\begin{tabular}{|c|c|c|c|c|c|c|c|}
\hline \multirow[t]{2}{*}{ Lembaga } & \multirow[t]{2}{*}{ Uraian } & \multicolumn{2}{|c|}{ Pola III } & \multicolumn{2}{|c|}{ Pola IV } & \multicolumn{2}{|c|}{ Pola V } \\
\hline & & $\begin{array}{l}\text { Biaya } \\
\text {-(Rp)- }\end{array}$ & $\begin{array}{l}\text { Share } \\
--(\%)--\end{array}$ & $\begin{array}{c}\text { Biaya } \\
--(\mathrm{Rp})--\end{array}$ & $\begin{array}{l}\text { Share } \\
--(\%)--\end{array}$ & $\begin{array}{c}\text { Biaya } \\
\text {--(Rp)-- }\end{array}$ & $\begin{array}{l}\text { Share } \\
--(\%)--\end{array}$ \\
\hline Petani & a. Harga Jual & $1.512,5$ & 30,4 & $1.512,5$ & 31,7 & $1.512,5$ & 30,4 \\
\hline \multirow[t]{5}{*}{ Tengkulak } & a. Harga Beli & $1.512,5$ & 30,4 & $1.512,5$ & 31,7 & $1.512,5$ & 30,4 \\
\hline & b.Biaya Distribusi & 74,0 & 1,5 & 74,05 & 1,6 & 74,05 & 1,5 \\
\hline & c. Marjin Distribusi & 450,0 & 9,1 & 450,0 & 9,4 & 450,0 & 9,1 \\
\hline & d. Profit & 376,0 & 7,6 & 376,0 & 7,9 & 375,95 & 7,6 \\
\hline & e. Harga Jual & $1.962,5$ & 39,5 & $1.962,5$ & 41,1 & 1962,5 & 39,5 \\
\hline \multirow[t]{5}{*}{ Pengepul Pasar } & a. Harga Beli & - & - & $1.962,5$ & 41,1 & 1962,5 & 39,5 \\
\hline & b.Biaya Distribusi & - & - & 74,28 & 1,6 & 74,28 & 1,5 \\
\hline & c. Marjin Distribusi & - & - & 912,5 & 19,1 & 400,0 & 8,0 \\
\hline & d. Profit & - & - & 838,22 & 17,6 & 325,7 & 6,6 \\
\hline & e. Harga Jual & - & - & $2.875,0$ & 60,2 & $2.362,5$ & 47,5 \\
\hline \multirow[t]{5}{*}{ Pedagang Besar } & a. Harga Beli & $1.962,5$ & 39,5 & - & - & $2.362,5$ & 47,5 \\
\hline & b. Biaya Distribusi & 73,0 & 1,5 & - & - & 69,52 & 1,4 \\
\hline & c. Marjin Distribusi & $1.620,8$ & 32,6 & - & - & $1.220,8$ & 24,6 \\
\hline & d. Profit & $1.547,8$ & 31,1 & - & - & $1.151,28$ & 23,2 \\
\hline & e. Harga Jual & $3.583,3$ & 72,1 & - & - & $3.583,3$ & 72,1 \\
\hline Pedagang & a. Harga Beli & $3.583,3$ & 72,1 & $2.875,0$ & 60,2 & $3.583,3$ & 72,1 \\
\hline \multirow[t]{4}{*}{ Pengecer } & b. Biaya Distribusi & 72,45 & 1,4 & 109,92 & 2,3 & 72,46 & 1,3 \\
\hline & c. Marjin Distribusi & $1.388,1$ & 27,9 & $1.900,0$ & 39,8 & $1.388,1$ & 27,9 \\
\hline & d. Profit & $1.315,7$ & 26,5 & $1.790,08$ & 37,5 & $1.315,64$ & 26.5 \\
\hline & e. Harga Jual & $4.971,4$ & 100 & $4.775,0$ & 100 & $4.971,4$ & 100,00 \\
\hline \multicolumn{2}{|c|}{ Total Biaya $(\mathrm{Rp} / \mathrm{Kg})$} & 219,69 & & 258,26 & & 290,31 & \\
\hline
\end{tabular}

\subsection{Efisiensi Distribusi}

Berdasarkan Tabel 2. diketahui bahwa nilai farmer's share pada pola distribusi I, II, III, IV, dan V secara berurutan adalah $64 \%, 53 \%, 30 \%$, $32 \%$, dan $30 \%$. Perbedaan nilai farmer's share dipengaruhi oleh tingkat marjin distribusi produk serta jumlah lembaga distribusi yang terlibat pada tiap pola distribusi. Hastian (2010) berpendapat bahwa nilai farmer's share dapat digunakan sebagai salah satu indikator untuk menentukan tingkat efisiensi sebuah pola distribusi. Hal ini didukung oleh pendapat Ruauw (2015) bahwa indikator efisiensi distribusi selain marjin distribusi adalah farmer's share, dimana farmer's share memiliki hubungan negatif dengan marjin distribusi. Nilai marjin distribusi yang semakin 
tinggi akan membuat nilai farmer's share semakin rendah, begitupun sebaliknya. Berdasarkan data yang telah diperoleh, dapat diketahui bahwa pola distribusi yang termasuk kategori efisien berdasarkan analisis farmer's share adalah pola distibusi I dan II dimana pada pola tersebut diperoleh nilai farmer's share lebih dari $50 \%$.

Tabel 2. Analisis Farmer's share dalam Rantai Distribusi Labu Siam di Kabupaten Semarang.

\begin{tabular}{|c|c|c|c|c|c|c|c|c|}
\hline Pola & Deskripsi & $\begin{array}{c}\text { Harga } \\
\text { Jual } \\
\text { Tingkat } \\
\text { Petani }\end{array}$ & $\begin{array}{c}\text { Harga Jual } \\
\text { Tingkat } \\
\text { Pedagang } \\
\text { Pengecer }\end{array}$ & $\begin{array}{c}\text { Biaya } \\
\text { Distribusi }\end{array}$ & $\begin{array}{c}\text { Marjin } \\
\text { Distribusi }\end{array}$ & $\begin{array}{c}\text { Farmer's } \\
\text { Share }\end{array}$ & $\begin{array}{l}\text { Efi } \\
\text { sie } \\
\text { nsi }\end{array}$ & $M M E$ \\
\hline & & & 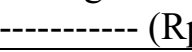 & & - & 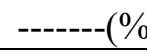 & ---- & \\
\hline I & $\mathrm{P}-\mathrm{T}-\mathrm{K}$ & $1.512,5$ & 2.380 & 74,05 & 862,5 & 64 & 3,1 & 1,615 \\
\hline II & $\mathrm{P}-\mathrm{T}-\mathrm{PP}-\mathrm{K}$ & $1.512,5$ & 2.875 & 148,33 & $1.362,5$ & 53 & 5,2 & 1,001 \\
\hline III & $\mathrm{P}-\mathrm{T}-\mathrm{PB}-\mathrm{PE}-\mathrm{K}$ & $1.512,5$ & 4.971 & 219,69 & $3.458,5$ & 30 & 4,4 & 0,411 \\
\hline IV & $\mathrm{P}-\mathrm{T}-\mathrm{PP}-\mathrm{PE}-\mathrm{K}$ & $1.512,5$ & 4.775 & 247,29 & $3.262,5$ & 32 & 5,2 & 0,431 \\
\hline $\mathrm{V}$ & $P-T-P P-P B-P E-K$ & $1.512,5$ & 4.971 & 290,31 & $3.458,5$ & 30 & 5,8 & 0,404 \\
\hline
\end{tabular}

Keterangan :

$\mathrm{P}=$ Petani $\quad \mathrm{T}=$ Tengkulak

$\mathrm{PP}=$ Pedagang pengumpul

$\mathrm{PB}=$ Pedagang besar

$\mathrm{PE}=$ Pedagang eceran

$\mathrm{K}=$ Konsumen

Hal ini sesuai dengan pendapat Sudiyono (2002) yang menyatakan sebuah pola rantai distribusi dapat dinyatakan efisien apabila nilai farmer's sharenya lebih dari 50\%. Nilai efisiensi distribusi pada masing-masing pola $<33 \%$, maka semua pola distribusi dinilai telah efisien berdasarkan nilai efisiensinya. Nilai MME pada sebuah saluran distribusi menunjukkan tingkat efisiensi distribusi produknya, dimana semakin tinggi nilai MME maka semakin efisien saluran distribusi tersebut. Pola saluran distribusi yang paling efisien berdasarkan nilai farmer's share, nilai efisiensi distribusi, dan nilai MME adalah pola saluran I, pola saluran I adalah pola saluran terpendek dimana hanya terdapat produsen, 1 lembaga perantara, dan konsumen akhir. Hal tersebut sesuai pendapat Praswati dkk (2018) bahwa semakin pendek rantai distribusi dan makin rendah nilai marjin, maka semakin tinggi tingkat efisiensi distribusi tersebut.

\subsection{Uji ANOVA dan Uji Bonferroni}

Uji ANOVA digunakan untuk menguji adanya perbedaan total marjin distribusi pada setiap pola. Berdasarkan output SPSS pada tabel 3. diketahui nilai Levene Statistic sebesar 2,370 dan nilai siginifikansi sebesar 0,074. Nilai siginifikansi 0,074 lebih dari 0,05 maka disimpulkan bahwa varian marjin distribusi homogen, sehingga dilakukan uji bonferroni sebagai uji lanjutan atau uji Post hoc. Berdasarkan uji ANOVA dengan SPSS diperoleh nilai signifikansi sebesar 0,000 sehingga disimpulkan bahwa rata - rata marjin distribusi pada ke 5 pola memiliki perbedaan signifikan.

Tabel 3. Uji homogenitas varian data

\section{Test of Homogeneity of Variances}

marjin

Levene

Statistic

df1 $\mathrm{df} 2$ Sig.

\section{2,370}

4

31

, 074

Sumber : Data Primer Terolah,2019.

Hasil uji Bonferroni pada tabel 4. menunjukkan adanya perbedaan rata - rata marjin total pada beberapa pola distribusi. Pola I memiliki perbedaan marjin rata - rata yang signifikan dengan marjin rata - rata pola II, III, IV, dan V. Pola II memiliki perbedaan marjin rata rata yang signifikan dengan marjin rata - rata pola I, III, IV, dan V. Perbedaan rata-rata marjin distribusi pada suatu pola terhadap pola lain dapat diketahui berdasarkan tanda (*) pada kolom Mean difference (I-J), dimana tanda $(*)$ dapat diartikan bahwa terdapat perbedaan marjin distribusi ratarata yang signifikan antara pola pada kolom (I) terhadap pola pada kolom (J). 
Tabel 4. Hasil Uji Bonferroni untuk Menguji Perbedaan Marjin Total Setiap Pola Distribusi.

Multiple Comparisons

Dependent Variable: marjin Bonferroni

\begin{tabular}{|c|c|c|c|c|c|c|}
\hline \multirow[t]{2}{*}{ (I) Pola } & \multirow[t]{2}{*}{ (J) Pola } & \multirow{2}{*}{$\begin{array}{c}\text { Mean Difference } \\
(\mathrm{I}-\mathrm{J})\end{array}$} & \multirow{2}{*}{ Std. Error } & \multirow{2}{*}{ Sig. } & \multicolumn{2}{|c|}{ 95\% Confidence Interval } \\
\hline & & & & & Lower Bound & Upper Bound \\
\hline \multirow[t]{4}{*}{1,00} & 2,00 & $-500,00000^{*}$ & 86,65241 &, 000 & $-761,8738$ & $-238,1262$ \\
\hline & 3,00 & $-2596,42857^{*}$ & 89,69377 &, 000 & $-2867,4937$ & $-2325,3634$ \\
\hline & 4,00 & $-2400,00000^{*}$ & 93,59530 &, 000 & $-2682,8560$ & $-2117,1440$ \\
\hline & 5,00 & $-2596,42857^{*}$ & 89,69377 &, 000 & $-2867,4937$ & $-2325,3634$ \\
\hline \multirow[t]{4}{*}{2,00} & 1,00 & $500,00000^{*}$ & 86,65241 &, 000 & 238,1262 & 761,8738 \\
\hline & 3,00 & $-2096,42857^{*}$ & 89,69377 &, 000 & $-2367,4937$ & $-1825,3634$ \\
\hline & 4,00 & $-1900,00000^{*}$ & 93,59530 &, 000 & $-2182,8560$ & $-1617,1440$ \\
\hline & 5,00 & $-2096,42857^{*}$ & 89,69377 &, 000 & $-2367,4937$ & $-1825,3634$ \\
\hline \multirow[t]{4}{*}{3,00} & 1,00 & $2596,42857^{*}$ & 89,69377 & ,000 & 2325,3634 & 2867,4937 \\
\hline & 2,00 & $2096,42857^{*}$ & 89,69377 &, 000 & 1825,3634 & 2367,4937 \\
\hline & 4,00 & 196,42857 & 96,41790 & ,502 & $-94,9577$ & 487,8148 \\
\hline & 5,00 &, 00000 & 92,63533 & 1,000 & $-279,9549$ & 279,9549 \\
\hline \multirow[t]{4}{*}{4,00} & 1,00 & $2400,00000^{*}$ & 93,59530 &, 000 & 2117,1440 & 2682,8560 \\
\hline & 2,00 & $1900,00000^{*}$ & 93,59530 &, 000 & 1617,1440 & 2182,8560 \\
\hline & 3,00 & $-196,42857$ & 96,41790 &, 502 & $-487,8148$ & 94,9577 \\
\hline & 5,00 & $-196,42857$ & 96,41790 &, 502 & $-487,8148$ & 94,9577 \\
\hline \multirow[t]{4}{*}{5,00} & 1,00 & $2596,42857^{*}$ & 89,69377 &, 000 & 2325,3634 & 2867,4937 \\
\hline & 2,00 & $2096,42857^{*}$ & 89,69377 &, 000 & 1825,3634 & 2367,4937 \\
\hline & 3,00 &, 00000 & 92,63533 & 1,000 & $-279,9549$ & 279,9549 \\
\hline & 4,00 & 196,42857 & 96,41790 &, 502 & $-94,9577$ & 487,8148 \\
\hline
\end{tabular}

*.The mean difference is significant at the 0.05 level.

\section{Kesimpulan}

Berdasarkan hasil penelitian dan analisis yang telah dilakukan, diperoleh kesimpulan bahwa terdapat 5 pola distribusi labu siam di Kabupaten Semarang. Setiap pola distribusi melibatkan paling sedikit 1 lembaga distribusi. Marjin distribusi total pada pola I adalah $\mathrm{Rp}$ $862,5 / \mathrm{Kg}$; pola II adalah $\mathrm{Rp} 1.362,5 / \mathrm{Kg}$; pola III adalah Rp $3.458,9 / \mathrm{Kg}$; pola IV adalah $\mathrm{Rp}$ $3.262,5 / \mathrm{Kg}$ dan pola $\mathrm{V}$ adalah $\mathrm{Rp} 3.458,9 / \mathrm{Kg}$. Diketahui bahwa pola distribusi yang termasuk kategori efisien berdasarkan farmer's share adalah pola I dan pola II. Pola distribusi paling efisien berdasarkan nilai farmer's share, nilai efisiensi distribusi, dan nilai MME adalah pola distribusi I. Hasil uji ANOVA dan uji Bonferroni menunjukkan bahwa terdapat perbedaan signifikan pada marjin distribusi pola I terhadap pola II, III, IV, dan V, serta pola II terhadap pola I, III, IV, dan V.

\section{Daftar Pustaka}

Acharya, S. S. dan N. L. Agrawal. (2001). Agricultural Marketing in India. New Delhi : Oxford and IBH Publishing Company.
Adiansyah, N., A. Dja'far, dan Rifiana. (2013). Analisis tataniaga sawi di Kecamatan Liang Anggang Kota Banjarbaru. J. Agribisnis Perdesaan, 3(1), 62- 73.

Alamaini, W. O., Budiyanto, dan A. Mansyur. (2016) Margin Pemasaran Ikan Cakalang (Katsuwonus pelamis) di Tempat Pendaratan Ikan Sodohoa Kota Kendari Provinsi Sulawesi Tenggara. J. Sosial Ekonomi Perikanan FPIK Universitas Halu Oleo, 1(3), 136 - 142.

Azzaino. (1991). Pengantar Tataniaga Pertanian. Bogor : Departemen Ilmu - ilmu Sosial Ekonomi Institut Pertanian Bogor.

Badan Pusat Statistik. (2017). Jawa Tengah dalam Angka 2015. Jawa Tengah : BPS Jawa Tengah.

Badan Pusat Statistik. (2018). Kabupaten Semarang dalam Angka 2018. Semarang : BPS Kabupaten Semarang.

Dastagiri, M. B., R. Chand, T. K. Immanuelraj, C. V. Hanumanthaiah, P. Paramsivam, R. S. Sidhu, M. Sudha, S. Mandal, B. Singh, K. Chand, B. G. Kumar. (2013). Indian 
vegetables : production trends, marketing efficiency and export competitiveness. J. American Journal of Agriculture and Forestry. 1(1), $1-11$.

Fuad, M., Christin H., Nurlela, Sugiarto, Y.E.F. Paulus. (2000). Pengantar Bisnis. Jakarta : PT. Gramedia Pustaka Utama.

Hastian. (2010). Analisis efisiensi pengolahan dan Pemasaran Hasil Usahatani Kelapa di Kabupaten Bombana. J. Agriplus, 20 (01), $77-87$.

Kheirandish, M. dan M. V. Srinivasa Gowda. (2012). Marketing efficiency and price spread for saffron in Iran. J. Agriculture Economics, 5(1), 23 - 30.

Kotler, P. dan G. Amstrong. (2004). Dasar - Dasar Pemasaran Jilid ke - 2. Indeks, Jakarta.

Muslim, C. dan V. Darwis. (2012). Keragaan Kedelai Nasional dan Analisis Farmer Share serta Efisiensi Saluran Pemasaran Kedelai di Kabupaten Cianjur. J. SEPA, $9(1), 1-11$.

Pradika, A., A. I. Hasyim, dan A. Soelaiman. (2013). Analisis Efisiensi Pemasaran Ubi Jalar di Kabupaten Lampung Tengah. J. Ilmu-ilmu Agribisnis. 1(1), 25 - 35 .

Praswati, A. N., T. Prijanto, dan B. D. Aji. (2018). Saluran Distribusi dan Marjin Pemasaran Kubis Tomat Wortel (Studi Kasus di Area Boyolali Jawa Tengah). J. Ilmu Manajemen dan Akuntansi Terapan, 9(1), $1-18$.

Ruauw, E. (2015). Kajian Distribusi Pangan Pokok Beras di Kabupaten Kepulauan Talud. J. ASE. 11(1), $58-68$.

Sari, D. P. (2014). Optimasi Distribusi Gula Merah pada UD. Sari Bumi Raya Menggunakan Model Transportasi dan Metode Least Cost. Skripsi Sarjana. Universitas Dian Nuswantoro.

Sudiyono, A. 2002. Pemasaran Pertanian. 2 edisi 2. Malang : UMM Press. 